\title{
INTERACTIONS BETWEEN INDIVIDUAL PLANT SPECIES AND SOIL NUTRIENT STATUS IN SHORTGRASS STEPPE ${ }^{\prime}$
}

\author{
MARY ANN VINTON \\ Graduate Degree Program in Ecology and the Department of Forest Sciences, \\ Colorado State University, Fort Collins, Colorado 80523 USA \\ INGRID C. BURKE \\ Graduate Degree Program in Ecology and the Department of Forest Sciences, \\ Colorado State University, Fort Collins, Colorado 80523 USA, and \\ Natural Resource Ecology Laboratory, Colorado State University, Fort Collins, Colorado 80523 USA
}

Abstract. The effect of plant community structure on nutrient cycling is fundamental to our understanding of ecosystem function. We examined the importance of plant species and plant cover (i.e., plant covered microsites vs. bare soil) on nutrient cycling in shortgrass steppe of northeastern Colorado. We tested the effects of both plant species and cover on soils in an area of undisturbed shortgrass steppe and an area that had undergone nitrogen and water additions from 1971 to 1974 , resulting in significant shifts in plant species composition.

Soils under plants had consistently higher $\mathrm{C}$ and $\mathrm{N}$ mineralization rates and, in some cases, higher total and microbial $\mathrm{C}$ and $\mathrm{N}$ levels than soils without plant cover. Four native grasses, one sedge, and one shrub differed from one another in the quantity and quality of above- and belowground biomass but differences among the six species in soil nutrient cycling under their canopies were slight. However, soils under bunchgrasses tended to have higher $\mathrm{C}$ mineralization and microbial biomass $\mathrm{C}$ than soil under the rhizomatous grass, Agropyron smithii. Also, the one introduced annual in the study, Kochia scoparia, had soils with less plant-induced heterogeneity and higher rates of $\mathrm{C}$ and $\mathrm{N}$ mineralization as well as higher levels of microbial biomass $C$ than soils associated with the other species. This species was abundant only on plots that had received water and nitrogen for a 4-yr period that ended $20 \mathrm{yr}$ ago, where it has persisted in the absence of resource additions for $20 \mathrm{yr}$, suggesting a positive feedback between plant persistence and soil nutrient status.

Plant cover patterns had larger effects on ecosystem scale estimates of soil properties than the attributes of a particular plant species. This result may be due to the semiarid nature of this grassland in which plant cover is discontinuous and decomposition and nutrient availability are primarily limited by water, not by plant species-mediated characteristics such as litter quality. That local plant-induced patterns in soil properties significantly affected ecosystem scale estimates of these properties indicates that consideration of structural attributes, particularly plant cover patterns, is critical to estimates of ecosystem function in shortgrass steppe.

Key words: carbon; disturbance; functional groups; island of fertility; nitrogen; nutrient cycling; plant-soil feedback; shortgrass steppe; soil heterogeneity.

\section{INTRODUCTION}

Individual plant characteristics, such as life-span, biomass allocation, and tissue chemical composition have been shown to have significant effects on ecosystem processes such as soil organic matter and nutrient dynamics (Melillo et al. 1982, Pastor et al. 1984, Pastor and Post 1986, Vitousek et al. 1987, Berendse et al. 1989, Matson 1990, Binkley and Valentine 1991, Johnson and Damman 1991). Many of these studies showing significant plant species effects on nutrient cycling have been conducted in forests or in systems undergoing primary succession. Recent work in tallgrass prairie suggests that grass species have differential effects on nutrient availability, with important

Manuscript received 6 December 1993; revised 8 July 1994; accepted 11 July 1994. potential consequences for species interactions and successional processes (Tilman 1986, Inouye and Tilman 1988, Wedin and Tilman 1990, Tilman and Wedin 1991). In drier shrub and grassland ecosystems, individual plants concentrate biomass in soils beneath their canopies, forming "islands of soil fertility" (e.g., Charley and West 1977). Individual plants, both by virtue of their tissue quantity and quality, as well as their presence in systems with sparse plant cover, may play important roles in ecosystem level nutrient cycling.

The importance of these plant species-ecosystem relationships lies in the potential for positive feedbacks to exist between species and ecosystem variables; for example, between species litter quality and decomposition rate (Pastor and Post 1986, Hobbie 1992), and thus for species-induced changes to persist and be important regulators of ecosystem structure and function. 
Pastor and Post (1986) used a simulation model of forest nutrient cycling to demonstrate that feedbacks between plant species litter characteristics and soil nutrient levels have important implications for forest species dynamics and ecosystem development through time. This feedback potential is particularly important for systems undergoing significant changes in species composition, such as those resulting from human intervention.

Individual plant canopy presence or absence can also be an important cause of small-scale patterns of nutrient availability (Charley and West 1977, Robertson et al. 1988, Burke 1989, Burke et al. 1989, Jackson and Caldwell 1993). In arid to semiarid areas, patterns of plant-covered microsites vs. bare-ground microsites are a major determinant of soil nutrient patterns (Charley and West 1977, Bolton et al. 1990, Schlesinger et al. 1990), and may affect subsequent plant establishment (Padien and Lajtha 1992). In shortgrass steppe, patterns in plant presence or absence of the dominant plant species have significant effects on patterns of microbial activity and nutrient availability (Hook et al. 1991). Population factors (i.e., seed dispersal and plant lifespan), by influencing the spatial patterning and turnover of plants, may determine the degree of spatial heterogeneity in resource availability (Lauenroth et al., in press) and, potentially, ecosystem stability (Schlesinger et al. 1990).

The literature summarized above on individual plant effects on soil properties can be divided into two groups: (1) studies on the relationships and feedbacks between plant tissue chemical content and soil nutrient availability and (2) studies, largely in semiarid to arid areas with discontinuous plant cover, relating plant canopy presence to properties of the soil beneath the canopy. In our system, the shortgrass steppe of northeastern Colorado, we have both discontinuous plant cover and a mix of plant life-forms and species, allowing for both plant presence as well as plant life-form and tissue chemistry to have important effects on soils. Our system is characterized by the dominant $\mathrm{C}_{4}$ bunchgrass, Bouteloua gracilis, with a mix of other grasses, forbs, and shrubs, and a significant amount of bare ground between individual plants. In investigating the importance of individual plants to nutrient cycling in the shortgrass steppe, it is necessary to consider both plant canopy presence and tissue chemical characteristics to completely address the issue.

Our primary objective in this study was to examine the influence of individual plants of several species on the local pattern of carbon and nitrogen cycling in the soil of shortgrass steppe. We were interested in determining what characteristics of individual plant species, such as tissue chemical composition, biomass allocation, or life history qualities, were most important in explaining effects on soil properties. We expected plant litter characteristics such as lignin, lignin to nitrogen ratios, or carbon to nitrogen ratios would reflect litter quality for decomposers and thus explain patterns in decomposition rate and nutrient availability (Melillo et al. 1982). Similarly, we expected plant production and allocation measures to reflect the amount of material available for decomposition and nutrient release. We expected plant life-span to influence the spatial pattern of plants on the landscape through time, with shortlived plants in place for less time than long-lived plants. Plant life-form should also affect the spatial pattern of biomass on the landscape, with bunchgrasses forming more concentrated locations of biomass than rhizomatous grasses. Thus, we expected both plant life-span and life-form to affect the spatial pattern of soil resources.

A secondary objective was to evaluate these plantsoil relationships in the context of a major historical disturbance to soil resources: the addition of water and nitrogen from 1970 to 1974 , which may have significantly changed these plant-soil relationships. The addition of these resources changed species composition dramatically, and some of the changes have persisted to the present, $20 \mathrm{yr}$ after the resource addition ceased. We think this persistent response may represent an example of positive feedback between plants and soils, i.e., soil fertility was enhanced via artificial additions, plant species composition or physiology changed in response to the enhanced resources, and in turn, plants may have subsequently altered or maintained this enhanced resource regime. Comparisons of species effects on soils in the unaltered plots with species effects on soils in the historically resource-amended plots indicate how native, shortgrass steppe species influence soils under more or less "steady-state" conditions, as well as how plant species and soils interact under a perturbed nutrient regime.

Our third objective was to examine the importance of these local plant-induced effects on soils for determining larger scale ( 1 ha) estimates of ecosystem processes. If individual plant species do indeed affect local patterns of soil carbon and nitrogen dynamics, how do these small-scale, plant-induced patterns scale up to ecosystem level nitrogen and carbon budgets? To estimate large-scale budgets, is it necessary to sample small-scale heterogeneity? Again, we evaluated this question in the context of the historical resource disturbance to see if, under dynamic resource and plant conditions, the action of individual plant species could contribute to significant changes in soil carbon and nitrogen levels and turnover rates.

\section{METHODS \\ Site description}

Studies were conducted at the Central Plains Experimental Range (CPER, $40^{\circ} 49^{\prime} \mathrm{N}$ latitude, $107^{\circ} 46^{\prime}$ W longitude), $61 \mathrm{~km}$ northeast of Fort Collins on the north-central Colorado piedmont. The mean annual precipitation at the site is $309 \mathrm{~mm}$ and mean monthly 
TABLE 1. Plant species characteristics and relative percentage basal cover of plant species and bare ground in 1991 on plots in shortgrass steppe receiving additional nitrogen $(\mathrm{N})$, additional water $(\mathrm{W})$, both additional nitrogen and water $(\mathrm{NW})$, or nothing (Control) from 1970 to 1974.

\begin{tabular}{|c|c|c|c|c|c|c|}
\hline \multirow[b]{2}{*}{ Species } & \multirow[b]{2}{*}{ Phenology* } & \multirow[b]{2}{*}{ Life-span and growth form } & \multicolumn{4}{|c|}{ Relative basal cover (\%) } \\
\hline & & & Control & $\mathrm{N}$ & NW & W \\
\hline Agropyron smithii & Cool season & Perennial mid-rhizomatous grass & 4.9 & 5.3 & 4.6 & 5.1 \\
\hline Stipa comata & Cool season & Perennial mid-bunchgrass & 11.3 & 10.5 & 5.0 & 19.2 \\
\hline Bouteloua gracilis & Warm season & Perennial short bunchgrass & 31.6 & 31.1 & 6.3 & 24.8 \\
\hline Aristida longiseta & Warm season & Perennial mid-bunchgrass & 12.2 & 6.1 & 3.3 & 16.8 \\
\hline Artemisia frigida & Cool season & Perennial half shrub & 19.2 & 30.7 & 4.5 & 14.2 \\
\hline Carex eleocharis & Cool season & Perennial sedge & & & 38.0 & \\
\hline Kochia scoparia & Warm season & Annual forb & & & 35.5 & \\
\hline Bare ground & & & 20.9 & 16.3 & 2.9 & 19.8 \\
\hline
\end{tabular}

temperatures range from $-3^{\circ} \mathrm{C}$ in January to $22^{\circ} \mathrm{C}$ in July (Parton and Greenland 1987). The vegetation of the area is typical of shortgrass steppe and is dominated by the perennial bunchgrass, Bouteloua gracilis (H.B.K.) Lag. ex Griffiths. Other common species include the perennial grass, Buchloë dactyloides (Nutt.) Engelm.; the half-shrubs, Gutierrezia sarothrae (Pursh) Britt. and Rusby and Artemisia frigida Willd.; the forb, Sphaeralcea coccinea (Pursh) Rydb.; and the succulent, Opuntia polyacantha Haw. All plant nomenclature follows the Great Plains Flora Association (1986).

We sampled plants and soils on an area that was part of a fertilization and irrigation experiment in the early 1970s (Lauenroth et al. 1978). The experiment consisted of a factorial combination of four treatments with two replicates: control (no resource addition), water (W), nitrogen (N) and nitrogen plus water (NW) additions. The eight cells of the design were contiguous plots of area 1 ha each, randomly assigned within the two blocks. Water and nitrogen fertilizer were applied from 1970 to 1974 . Water was applied to maintain soil water potential at a depth of $10 \mathrm{~cm}$ between 0 and $-0.08 \mathrm{MPa}$ from 1 May to 1 September (Lauenroth et al. 1978). Soil water was checked daily and, if needed, water was added at night with sprinklers. The amount of water added per year ranged from 458 to $707 \mathrm{~mm}$ (Lauenroth et al. 1978). Nitrogen fertilizer $(330 \mathrm{~g} / \mathrm{kg}$ nitrogen as ammonium nitrate) was added to maintain a difference between the treatment and control plots of at least $50 \mathrm{~kg} / \mathrm{ha}$ of soil mineral nitrogen $\left(\mathrm{NO}_{3}{ }^{-}\right.$and $\mathrm{NH}_{4}{ }^{+}$). This resulted in addition of $100-150 \mathrm{~kg} / \mathrm{ha}$ of nitrogen to the nitrogen treatment plots in each of the four years. Water and nitrogen additions were stopped in 1974 and since then, except for some vegetation and soil sampling, the plots have been unaltered. The plots have been protected from cattle grazing since 1968 .

The major effects of resource additions were a 5-10 fold increase in net primary production and large changes in species composition via colonization by alien species and shifts in the relative dominance of native species (Dodd and Lauenroth 1978, Lauenroth et al. 1978, Lauenroth and Dodd 1979). When resource additions were stopped, the plant community in the treated areas had reached a new state in terms of relative abundance of species (Dodd and Lauenroth 1978, Lauenroth et al. 1978, Lauenroth and Dodd 1979) which has persisted, with some fluctuations in species relative abundance, into the present (Milchunas et al. 1990, Milchunas and Lauenroth 1995).

\section{Tissue sampling and analyses}

We sampled plant tissue and soils under plants of five species on each of the historical treatment plots (Table 1). These species were selected because they represented the majority of the biomass on the plots and because they represented a variety of life-forms. The species were: Bouteloua gracilis (H.B.K.) Lag. ex Griffiths, a perennial $\mathrm{C}_{4}$ bunchgrass; Aristida longiseta Steud., a perennial $\mathrm{C}_{4}$ bunchgrass; Stipa comata Trin. and Rupr., a perennial $\mathrm{C}_{3}$ bunchgrass; Agropyron smithii Rydb., a perennial $\mathrm{C}_{3}$ rhizomatous grass; and $A r$ temisia frigida, a perennial half-shrub. Two other species, Carex eleocharis Bailey, a perennial $\mathrm{C}_{3}$ sedge, and Kochia scoparia (L.) Schrad., an annual $\mathrm{C}_{4}$ forb, were sampled only on the NW historical treatment plots. These two species were abundant on the NW historical treatment plots, but were rare or not present in the other plots (Table 1).

Aboveground biomass and cover estimates were obtained for each target species by randomly locating six rectangular quadrats of area $0.1 \mathrm{~m}^{2}$ along transects in each replicate of the historical treatment plots. We estimated percentage basal cover, counted the number of individuals, and clipped all aboveground plant material of each target species in each quadrat. The plant material was sorted into leaves, stems, and seeds and was dried at $55^{\circ} \mathrm{C}$ for $48 \mathrm{~h}$ before weighing.

Belowground biomass was sampled by removing a $2.2 \mathrm{~cm}$ diameter $\times 30 \mathrm{~cm}$ deep core from the soil immediately underneath each plant. Cores were taken from 32 individuals of each species on each plot of only one replicate of the historical treatment area. One transect was formed diagonally across each 1-ha his- 
torical treatment plot, and individual plants were chosen along the transect in a stratified, random manner at 16 locations. Root cores from two individual plants at each of the 16 locations were composited to provide enough root material for each sample. The belowground plant material was separated from the soil with the flotation method of Lauenroth and Whitman (1971), using a $0.5-\mathrm{mm}$ mesh sieve to catch fine roots. Roots were separated from culms or stem bases and all parts were dried at $55^{\circ}$ and weighed. The roots and stem bases were milled to pass through no. $40(0.5 \mathrm{~mm})$ mesh and subsamples were ashed at $550^{\circ} \mathrm{C}$.

Total percentage carbon and nitrogen were determined on both aboveground and belowground plant tissue using a nitrogen/carbon analyzer (Carlo-Erba, Fison Instruments, Saddlebrook, New Jersey). Lignin analyses were conducted on composited subsets of the tissue samples, using a modified Van Soest (1963) procedure (Waldern 1971).

\section{Soil sampling and analyses}

We sampled soils directly under plants of each species and in adjacent openings between plants by taking $5 \mathrm{~cm}$ diameter $\times 10 \mathrm{~cm}$ deep soil cores. Samples from between plants were taken on bare ground $\geq 10 \mathrm{~cm}$ from the target plant and neighboring plant canopies. Samples from under plants were taken at the location where a stem or a group of stems emerged from the soil. We took "under-plant" and "between-plant" cores from a total of four plants of each species, randomly located along transects, from each replicate of the historical treatment plots. Cores from two plants were composited for the laboratory analyses. This resulted in four soil samples analyzed for each historical treatment $x$ species $\times$ position combination. Soil samples were placed in coolers immediately and were transported to a laboratory refrigerator within $7 \mathrm{~h}$ after collection. All fresh soil analyses were performed within $3 \mathrm{~d}$ after collection.

Fresh soils were sieved to separate plant material and fragments $>2 \mathrm{~mm}$ in diameter. The soils were then weighed, mixed, and divided into subsamples for four analyses: water content, initial inorganic $\mathrm{N}$, incubations to determine potential net $\mathrm{N}$ and $\mathrm{C}$ mineralization, and microbial biomass $\mathrm{N}$ and $\mathrm{C}$. Inorganic $\mathrm{N}$ was extracted from a $10 \mathrm{~g}$ subsample with $50 \mathrm{~mL}$ of $2 \mathrm{~mol} / \mathrm{L} \mathrm{KCl}$ (with phenylmercuric acetate added to prevent microbial growth) for $30 \mathrm{~min}$ on an orbital shaker to measure initial inorganic $\mathrm{N}$. The extracts were allowed to settle for $10 \mathrm{~min}$ and were filtered through Whatman no. 40 paper. The extracts were refrigerated until analyzed for nitrate and ammonium on a Lachat (Milwaukee, Wisconsin) autoanalyzer (EPA 1979).

For the soil incubation, a 25-g subsample was placed in a small beaker, brought to field capacity with deionized water, and placed in a closed mason jar with 20 $\mathrm{mL}$ of deionized water in the bottom to maintain a saturated atmosphere (Schimel 1986). Five $\mathrm{mL}$ of 2 $\mathrm{mol} / \mathrm{L} \mathrm{NaOH}$ in a small vial was added to the jar to serve as a base trap for $\mathrm{CO}_{2}$ respired by soil microbes (Schimel 1986). The samples were incubated at $25^{\circ}$ for $30 \mathrm{~d}$. At the end of the incubation, soils were extracted with $\mathrm{KCl}$, filtered, and analyzed for nitrate and ammonium as described above. The base trap was titrated with $1 \mathrm{~mol} / \mathrm{L} \mathrm{HCl}$ to determine the amount of $\mathrm{CO}_{2}$ released during incubation, or the potential $\mathrm{C}$ mineralization (Snyder and Trofymow 1984). Potential net $\mathrm{N}$ mineralization was calculated as the difference between initial and final inorganic $\mathrm{N}$ of the soil.

The chloroform fumigation-extraction procedure (Powlson and Jenkinson 1976, Brookes et al. 1985) was used to measure microbial biomass in the soil samples. A 10-g subsample of fresh, sieved soil was extracted with $50 \mathrm{~mL}$ of $0.5 \mathrm{~mol} / \mathrm{L} \mathrm{K}_{2} \mathrm{SO}_{4}$ for $30 \mathrm{~min}$ on a 200 rpm orbital shaker and filtered through Whatman no. 40 paper. Another $10 \mathrm{~g}$ subsample of soil was fumigated with chloroform for $18 \mathrm{~h}$, vented for $5 \mathrm{~h}$, and extracted and filtered as described above. The control and fumigated soil extracts were frozen until they could be analyzed. Samples were thawed in warm water, ag itated for $10 \mathrm{~min}$, and allowed to settle overnight before they were analyzed the following day. Microbial biomass nitrogen was analyzed by the ninhydrin method (Amato and Ladd 1988). Microbial biomass carbon was obtained by a wet oxidation diffusion procedure (Snyder and Trofymow 1984) performed on the extracts. The air-dried soil samples were ground and dried at $55^{\circ}$ before total carbon and nitrogen contents were measured using a Carlo-Erba automated combustion analyzer.

\section{Statistical analyses}

For all of the soil response variables, the experimental design was treated as a split-split plot with historical treatment as the whole plot factor (with the whole plot factor being a randomized complete block), species as the subplot factor and position (under-plant vs. between-plant) as the sub-subplot factor (Table 2). We used the GLM procedure in SAS (SAS Institute 1985 ) to perform a 3-way analysis of variance (ANOVA) on the data. We used transformed data when necessary to satisfy the assumptions of the ANOVA. When ANOVA indicated a significant effect, we tested differences between means with techniques specific to split-split plot designs (Gomez and Gomez 1984), and the Scheffe procedure. We used contrast statements for specific comparisons between watered and unwatered plots (i.e., the $\mathrm{W}$ and $\mathrm{NW}$ plots vs. the control and $\mathrm{N}$ plots) and fertilized vs. unfertilized plots (i.e., the $\mathrm{N}$ and NW vs. the control and W plots). In the statistical analyses of soil variables, we tested for the effects of the five species sampled across the historical treatment area by restricting the analysis only to soils taken from under plants. This resulted in a split plot design, with historical treatment as the whole plot factor and species as the subplot factor. We used planned contrasts to 
TABLE 2. Results of a 3-way ANOVA using a split-split plot design, showing the significance of the effects of historical treatment (control, nitrogen, water, or nitrogen plus water additions from 1970 to 1974), species (both under and between plants of five different species), position (under vs. between plants) and factor interactions on soil response variables expressed on an area basis.*

\begin{tabular}{|c|c|c|c|c|c|c|c|c|c|c|c|c|}
\hline \multirow[b]{3}{*}{ Response } & \multicolumn{12}{|c|}{ Factors } \\
\hline & \multicolumn{2}{|c|}{ Treatment } & \multicolumn{2}{|c|}{ Species } & \multicolumn{2}{|c|}{ Position } & \multicolumn{2}{|c|}{ Trt. $\times$ species } & \multicolumn{2}{|c|}{ Trt. $\times$ position } & \multicolumn{2}{|c|}{$\begin{array}{l}\text { Species } \times \\
\text { position }\end{array}$} \\
\hline & $F$ & $P$ & $F$ & $P$ & $F$ & $P$ & $F$ & $P$ & $F$ & $P$ & $F$ & $P$ \\
\hline Soil carbon & 4.49 & 0.1246 & 0.98 & 0.4459 & 12.55 & 0.0020 & 0.83 & 0.6202 & 15.21 & 0.0001 & 1.26 & 0.3172 \\
\hline Soil nitrogen & 2.31 & 0.2551 & 1.15 & 0.3683 & 1.28 & 0.2721 & 1.05 & 0.4533 & 8.99 & 0.0006 & 0.93 & 0.4665 \\
\hline $\begin{array}{l}\text { Carbon } \\
\text { mineralization rate }\end{array}$ & 151 & ( 3720 & 053 & 00004 & 110 & 00001 & 135 & (0) 2847 & 530 & 00075 & 213 & 01153 \\
\hline $\begin{array}{l}\text { Nitrogen } \\
\text { mineralization rate }\end{array}$ & 93.48 & 0.0018 & 1.86 & 0.1666 & 30.92 & 0.0001 & 0.57 & 0.8385 & 3.09 & 0.0505 & 0.14 & 0.9660 \\
\hline $\begin{array}{l}\text { Microbial } \\
\text { biomass C }\end{array}$ & 9.79 & 0.0466 & 1.32 & 0.3051 & 3.12 & 0.0928 & 2.71 & 0.0325 & 0.80 & 0.5065 & 0.17 & 0.9495 \\
\hline $\begin{array}{l}\text { Microbial } \\
\text { biomass } \mathrm{N}\end{array}$ & 0.78 & 0.5788 & 4.26 & 0.0155 & 37.38 & 0.0001 & 0.46 & 0.9093 & 2.99 & 0.0553 & 0.25 & 0.9079 \\
\hline
\end{tabular}

* The soil variable means are illustrated for species and positions for the control plots in Fig. 1 and for the nitrogen plus water plots in Fig. 4. Also, means for the historical treatments and positions are shown in Fig. 6.

analyze species lifeform effects (e.g., bunchgrass vs. non-bunchgrass and $\mathrm{C}_{4}$ vs. $\mathrm{C}_{3}$ ) on soil properties.

For the aboveground biomass and tissue chemistry response variables for the five species on all historical treatment plots, the design was a split plot with historical treatment as the whole plot factor (the whole plot being a randomized complete block) and species as the subplot factor (Table 3).

We tested statistical hypotheses about the two species (Carex eleocharis and Kochia scoparia) that only occurred on the NW historical treatment plot by restricting the analysis to the NW plots. In this case, the design for the soil response variables was a split plot with species as the whole plot factor and position as the subplot factor. We used planned contrasts to compare the effects of the annual $K$. scoparia to the effects of the other, perennial species on soil properties. For the aboveground mass and tissue chemistry response variables, the design was a randomized complete block with the two NW replicates forming the blocks and species being the factor of interest.
For belowground mass and tissue chemistry response variables, we sampled only one of the historical treatment replicates, due to time constraints on root washing and sorting. We considered the historical treatment as the whole plot factor and the species as the subplot factor in a split plot design. In this case, we had no replication of the historical treatment, so we cannot make statistical inferences about the effects of historical treatment on belowground mass and tissue chemistry. However, we spatially replicated as much as possible by sampling 32 individuals across each entire historical treatment plot ( 1 ha area), so our inferences about historical treatment are unlikely to be affected by errors from local plot effects.

\section{Ecosystem-level estimates}

To estimate the impact of individual plants and species on larger scale ecosystem properties, we scaled up the individual plant level soil data using information about soil properties under and between plants and information about the relative cover of the plant species

TABLE 3. Results of a 2-way ANOVA using a split-plot design, showing the significance of the effects of historical treatment (control, nitrogen, water or nitrogen plus water additions from 1970 to 1974), plant species (five different species), and their interaction on plant biomass characteristics.*

\begin{tabular}{|c|c|c|c|c|c|c|}
\hline \multirow[b]{3}{*}{ Response } & \multicolumn{6}{|c|}{ Factor } \\
\hline & \multicolumn{2}{|c|}{ Historical treatment } & \multicolumn{2}{|c|}{ Species } & \multicolumn{2}{|c|}{$\begin{array}{l}\text { Historical treatment } \\
\times \text { species }\end{array}$} \\
\hline & $F$ & $P$ & $F$ & $P$ & $F$ & $P$ \\
\hline Aboveground biomass $\left(\mathrm{g} / \mathrm{m}^{2}\right)$ & 96.06 & 0.0018 & 44.94 & 0.0001 & 11.17 & 0.0001 \\
\hline Belowground biomass $\left(\mathrm{g} / \mathrm{m}^{2}\right)$ & 6.59 & 0.0003 & 37.28 & 0.0001 & 6.92 & 0.0001 \\
\hline Root : Shoot & 11.20 & 0.0001 & 77.25 & 0.0001 & 3.56 & 0.0001 \\
\hline Root C:N & 23.74 & 0.0001 & 7.53 & 0.0001 & 0.30 & 0.9869 \\
\hline Leaf C:N & 41.26 & 0.0001 & 47.76 & 0.0001 & 3.73 & 0.0001 \\
\hline Root lignin : $\mathrm{N}$ & 2.94 & 0.0765 & 3.10 & 0.0274 & $\ldots$ & $\ldots$ \\
\hline
\end{tabular}

* Fig. 2 shows the species means for plant biomass characteristics only on the control plots and Fig. 3 shows the species means for the nitrogen plus water plots. The means for plant biomass characteristics for the historical treatment plots are shown in Fig. 5. Lignin analyses were only performed for all species on one level of the historical treatment factor (control), so the historical treatment $\times$ species interaction for root lignin : $N$ could not be estimated. 
TABLE 4. Results of a 2-way ANOVA showing the significance of the effects of historical treatment ( $T$; treatments were control, nitrogen, water or nitrogen plus water additions from 1970 to 1974) and the estimate $(E)$ method used to scale up local measurements of soil properties to the plot scale.*

\begin{tabular}{|c|c|c|c|c|c|}
\hline Response & Factor & $\mathrm{df}$ & MS & $F$ & $P$ \\
\hline Total soil carbon & $\begin{array}{l}T \\
E \\
T \times E \\
\text { Error }\end{array}$ & $\begin{array}{r}3 \\
2 \\
6 \\
12\end{array}$ & $\begin{array}{r}33610 \\
5203 \\
5726 \\
2261\end{array}$ & $\begin{array}{r}14.86 \\
2.30 \\
2.53\end{array}$ & $\begin{array}{l}0.0002 \\
0.1426 \\
0.0805\end{array}$ \\
\hline Total soil nitrogen & $\begin{array}{l}T \\
E \\
T \times E \\
\text { Error }\end{array}$ & $\begin{array}{r}3 \\
2 \\
6 \\
12\end{array}$ & $\begin{array}{c}515 \\
5.7 \\
33.8 \\
94\end{array}$ & $\begin{array}{l}5.47 \\
0.06 \\
0.36\end{array}$ & $\begin{array}{l}0.0133 \\
0.9414 \\
0.8911\end{array}$ \\
\hline $\mathrm{C}$ mineralization & $\begin{array}{l}T \\
E \\
T \times E \\
\text { Error }\end{array}$ & $\begin{array}{r}3 \\
2 \\
6 \\
12\end{array}$ & $\begin{array}{l}0.300 \\
0.589 \\
0.030 \\
0.052\end{array}$ & $\begin{array}{r}5.78 \\
11.31 \\
0.058\end{array}$ & $\begin{array}{l}0.0111 \\
0.0017 \\
0.7388\end{array}$ \\
\hline $\mathrm{N}$ mineralization & $\begin{array}{l}T \\
E \\
T \times E \\
\text { Error }\end{array}$ & $\begin{array}{r}3 \\
2 \\
6 \\
12\end{array}$ & $\begin{array}{l}0.002 \\
0.001 \\
0.001 \\
0.0001\end{array}$ & $\begin{array}{r}10.78 \\
7.29 \\
0.88\end{array}$ & $\begin{array}{l}0.0010 \\
0.0085 \\
0.5353\end{array}$ \\
\hline Microbial biomass $\mathrm{C}$ & $\begin{array}{l}T \\
E \\
T \times E \\
\text { Error }\end{array}$ & $\begin{array}{r}3 \\
2 \\
6 \\
12\end{array}$ & $\begin{array}{r}14.35 \\
1.38 \\
0.99 \\
3.17\end{array}$ & $\begin{array}{l}4.53 \\
0.44 \\
0.31\end{array}$ & $\begin{array}{l}0.0240 \\
0.6566 \\
0.9176\end{array}$ \\
\hline Microbial biomass $\mathrm{N}$ & $\begin{array}{l}T \\
E \\
T \times E \\
\text { Error }\end{array}$ & $\begin{array}{r}3 \\
2 \\
6 \\
12\end{array}$ & $\begin{array}{l}0.007 \\
0.007 \\
0.001 \\
0.023\end{array}$ & $\begin{array}{l}0.32 \\
0.32 \\
0.03\end{array}$ & $\begin{array}{l}0.8137 \\
0.7347 \\
0.9998\end{array}$ \\
\hline
\end{tabular}

* Three estimate methods were used: the Bare Soil Estimate represents no consideration of plant effects on soils; the Plant Estimate includes effects of plant presence or absence, without consideration of differential cover among species; and the Species Estimate includes the effects of all major plant species, including their relative cover and nutrient cycling characteristics. See Methods for an explanation of how each estimate was calculated.

and bare ground in the historical treatment area (Table 1). We obtained the estimates of plant species cover using our own cover data and data from another study (D. Milchunas, personal communication), that provided an estimate of the relative cover of bare ground on each treatment plot. We standardized percentage basal cover estimates for the five species (seven in the NW historical treatment plots) plus bare ground to $100 \%$. We neglected the other species in the estimates since the five to seven sampled species represent $>80 \%$ of plant cover in the plots (D. Milchunas, personal communication).

We calculated three estimates of ecosystem level soil properties for each of the historical treatment areas. The first estimate, the "Bare Soil Estimate," is the between-plant soil properties applied to the entire area and represents the scaled-up soil property in a plot without the influence of individual plants. However, Bare Soil Estimate values could be affected by past influence of plants, since currently between-plant microsites could have been occupied by plants in the past. This is especially likely in the historical nitrogen and water addition plots. In many nutrient cycling studies of systems with discontinuous plant cover, only soils between plants are sampled, yet results are scaled up to represent the entire ecosystem, for bare as well as for plant-covered areas. Thus, we think this estimate is useful in demonstrating the implications of such a technique. The second estimate, the "Plant Estimate," is the sum of average properties of soils under all plants, multiplied by the average plant cover, and the average properties of soils between plants multiplied by average bare ground cover. The Plant Estimate takes into account the soil properties under the canopies of plants as well as the soil properties in the betweenplant microsites, but does not take into account the cover or nutrient cycling differences among species. The third estimate, the "Species Estimate," is the sum of the average soil property under each species, multiplied by the percentage cover of that species, and the average between-plant soil property, multiplied by percentage cover of bare ground. Thus, the Species Estimate takes into account not only average plant effects, but the different effects that plant species, by virtue of their cover and nutrient cycling properties, may have on ecosystem level soil properties. These different scaling techniques represent a range of information, from no information (Bare Soil Estimate) to detailed information (Species Estimate), about current plant- and species-specific effects on soil processes. Comparing results from the different estimates allowed us to assess the contribution of plant-specific information to ecosystem level conclusions. We used a 2-way ANOVA to see if historical treatment or estimate method significantly affected the results (Table 4). 

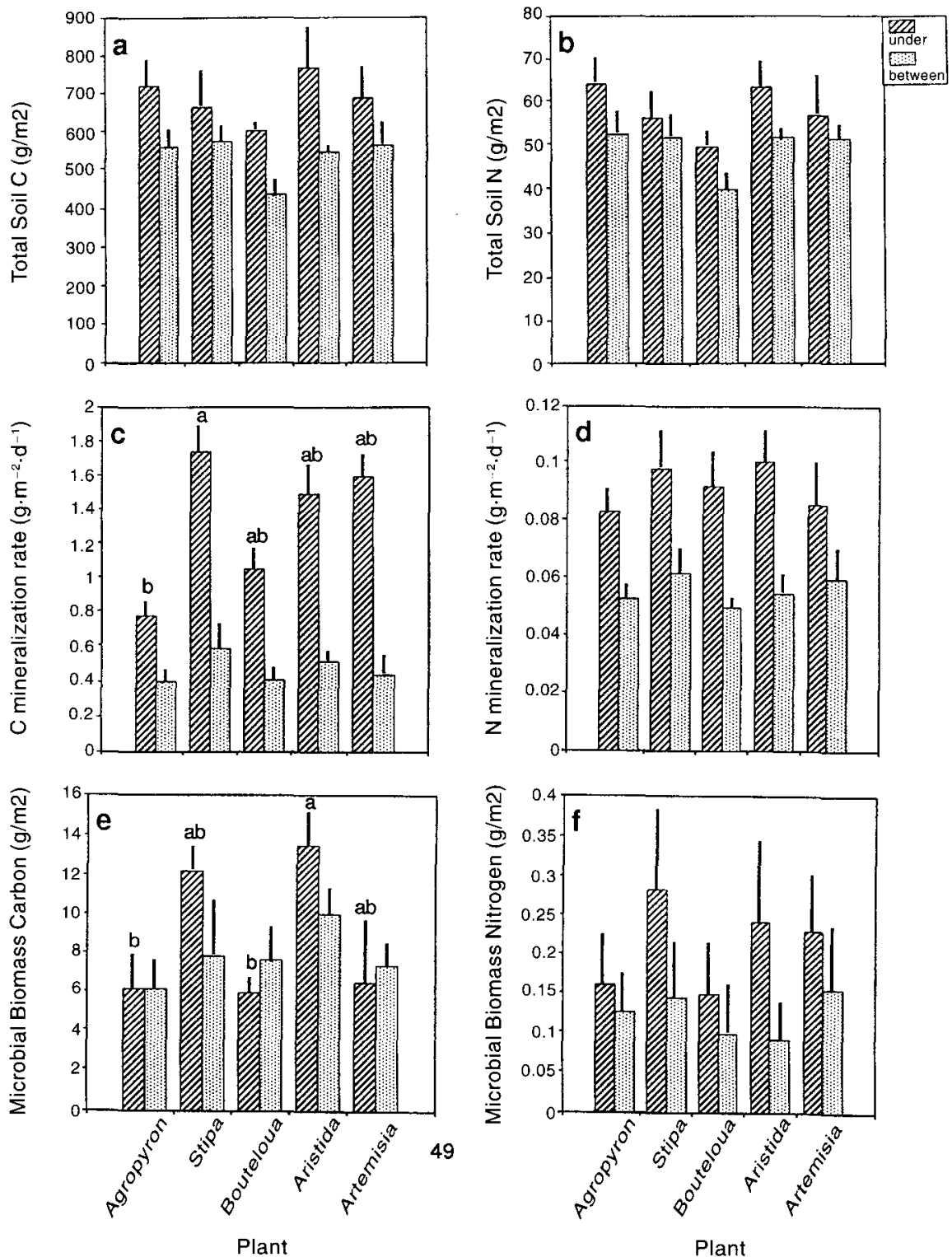

FIG. 1. Total soil carbon (a), total soil nitrogen (b), carbon mineralization rate (c), potential nitrogen mineralization rate (d), microbial biomass carbon (e), and microbial biomass nitrogen (f) in soils from under and between plants of the species Agropyron smithii, Stipa comata, Bouteloua gracilis, Aristida longiseta, and Artemisia frigida on control plots (unfertilized and unwatered) of a historical treatment area in shortgrass steppe. The vertical line on each bar indicates 1 SE. The small letters indicate cases where significant differences $(P<0.05)$ existed among species in soil properties under their canopies.

\section{RESULTS \\ Control plots}

Soil properties were affected by the five native, shortgrass species, and these effects were consistent over the historical treatments, i.e., there were no historical treatment $\times$ species interactions except for microbial biomass carbon (Table 2). Therefore, we will restrict our presentation of the effects of the five native, shortgrass species on soils to only the soils in the unaltered shortgrass steppe (Fig. 1). The five native short- grass species did not differ from one another in their effects on total soil pools of carbon or nitrogen in soils beneath their canopies (Fig. 1a, b). Species did differ in their effects on $\mathrm{C}$ mineralization; the bunchgrass, Stipa comata, had significantly higher $\mathrm{C}$ mineralization rates in soils under its canopy than did the rhizomatous grass, Agropyron smithii (Fig. 1c). Also, soils under the bunchgrasses, S. comata, Aristida longiseta, and Bouteloua gracilis, collectively, had significantly higher carbon mineralization rates than did the soils under A. smithii (Fig. 1c). Species identity had no effect on 

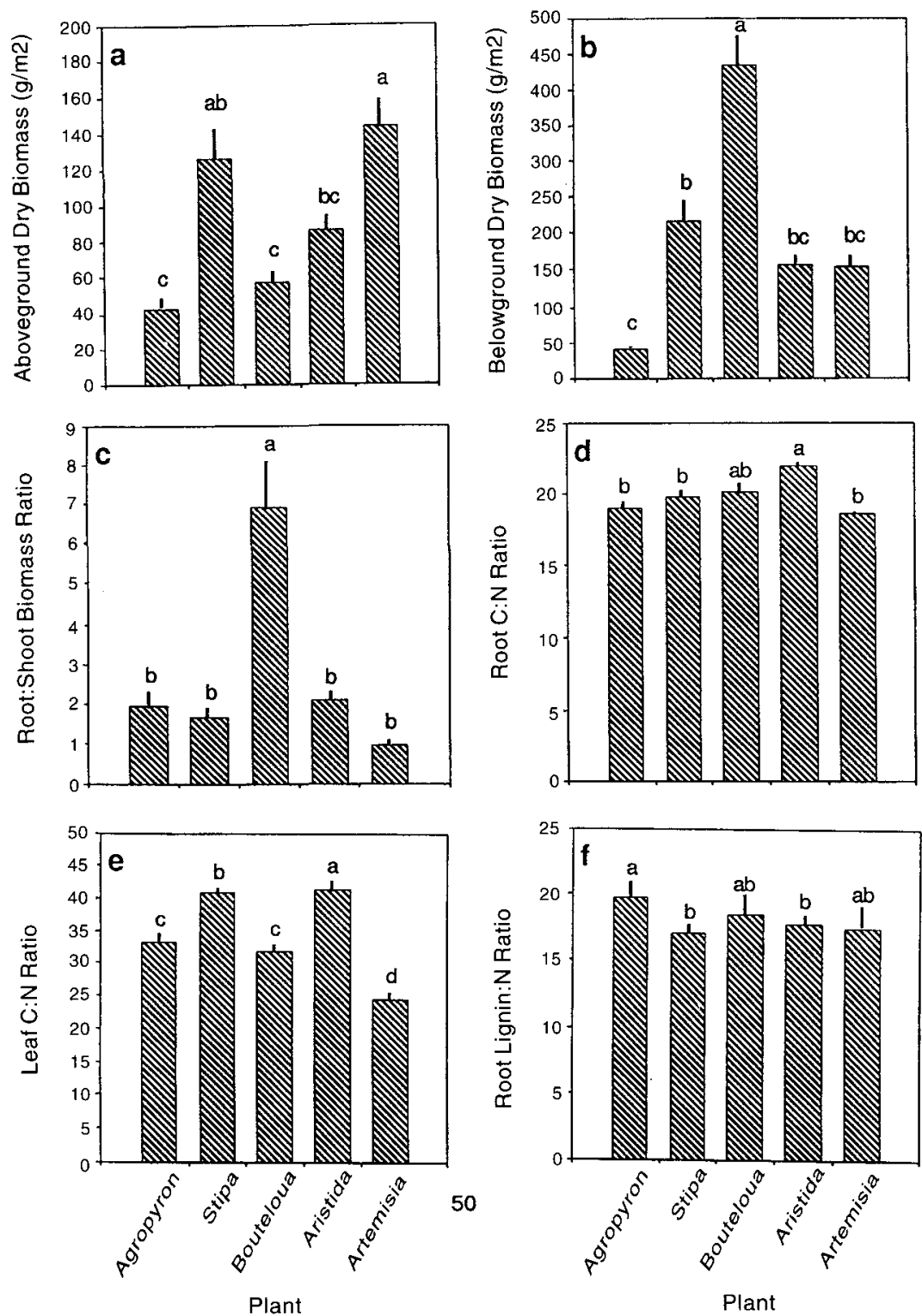

Fig. 2. Aboveground dry biomass (a), belowground dry biomass (b), root : shoot biomass ratio (c), root carbon : nitrogen ratio (d), leaf carbon : nitrogen ratio (e), and root lignin : nitrogen ratio (f) of Agropyron smithii, Stipa comata, Boutelouc gracilis, Aristida longiseta, and Artemisia frigida on control plots (unfertilized and unwatered) of a historical treatment area in shortgrass steppe. The vertical line on each bar indicates $1 \mathrm{SE}$. Bars with the same letters are not significantly different $(P \geq 0.05)$.

potential nitrogen mineralization rate or microbial biomass nitrogen (Fig. 1d, f). Microbial biomass carbon showed a response similar to carbon mineralization rates; soils under $A$. smithii had one of the lowest levels (Fig. 1e).

The quantity and quality of biomass differed substantially among the five species (Table 3, Fig. 2). The shrub, Artemisia frigida, had significantly more aboveground biomass than the grass species, with the exception of $S$. comata (Fig. 2a). The tall bunchgrass, $S$. comata, had the most aboveground biomass among the grasses. The dominant grass species of the shortgrass steppe, $B$. gracilis, had significantly more total belowground biomass than the other species (Fig. 2b). All of the bunchgrasses and the shrub had more belowground biomass than the rhizomatous grass, A. smithii (Fig. 2b). B. gracilis had much higher root to shoot ratios than the other species, which did not differ significantly from one another (Fig. 2c). Plant species also differed in tissue quality, or carbon : nitrogen and lignin : nitrogen ratios of above- and belowground tissue (Table 3 ). A. longiseta had significantly higher leaf $\mathrm{C}: \mathrm{N}$ ratios than 
the other species, and higher root $\mathrm{C}: \mathrm{N}$ ratio than the other species, with the exception of $B$. gracilis (Fig. 2d, e). A. smithii had significantly higher root lignin : nitrogen ratios than two of the other four species (Fig. 2f).

Plant position (under plants vs. between plants) exerted a strong and consistent effect on pool sizes and turnover rates of soil carbon and nitrogen in unaltered shortgrass steppe (Table 2, Fig. 1). Soils under plants had significantly higher rates of carbon and nitrogen mineralization and significantly more soil carbon, nitrogen, and microbial biomass nitrogen than soils from between plants (Fig. 1). Although species $\times$ position was not statistically significant for all the historical treatment plots, in the control plots the contrast in the between-plant and under-plant positions was greater for bunchgrasses than for non-bunchgrasses.

\section{NW treatment plots}

The historical NW plots had very different relative abundances of species than the historically unaltered control plots (Table 1). In the NW plots, much of the plant cover was composed of the species Kochia scoparia and Carex eleocharis, and correspondingly much less cover was composed of the other native shortgrass steppe species than in the control plots (Table 1). The non-invasive species in general had the same relative ranking in biomass quantity and quality on the NW plots as on the control plots (Figs. 2 and 3). However, there were some exceptions, and these contributed to the significant historical treatment $\times$ species interaction in the ANOVA for plant characteristics (Table 3). On the control plots, Bouteloua gracilis had much more belowground biomass than the other species, but on the NW plots, the amount of belowground biomass of $B$. gracilis was less than or similar to that of the other five native species (Figs. 2b and 3b). Also, Agropyron smithii had less aboveground biomass than most of the other species on the control plots, but ranked relatively high in aboveground biomass among the five native species on the NW plots (Figs. $2 \mathrm{a}$ and $3 \mathrm{a}$ ). Although plants on the NW plots in general had lower tissue $\mathrm{C}: \mathrm{N}$ than plants on the control plots, the relative rankings of the species tissue chemistry were similar between the control and NW plots (Figs. 2 and 3 ).

The major difference between the control and NW plots was the presence of the two invasive species on the NW plots and their virtual absence on the control plots. Thus, we compared the influence of the two invasive species, $K$. scoparia and $C$. eleocharis, to the influence of the other five species on plant and soil characteristics, all on the NW plots (Figs. 3 and 4). $K$. scoparia had significantly more aboveground biomass than the other species on the NW plots and both $K$. scoparia and $C$. eleocharis had significantly more belowground biomass per square metre than the other species (Fig. 3a, b). C. eleocharis had significantly higher root to shoot ratios than most other species (Fig.
$3 \mathrm{c})$. Both of these invasive species had lower belowground carbon to nitrogen ratios than the other species, except A. smithii (Fig. 3d), and both had significantly lower belowground lignin: nitrogen ratios than $A$. smithii and $B$. gracilis (Fig. 3f). Neither invasive species had significantly different effects on total soil carbon or nitrogen in soil beneath their canopies than the other species (Fig. 4a, b). However, soils associated with $K$. scoparia had significantly higher nitrogen mineralization rates, carbon mineralization rates and microbial biomass carbon than soils beneath the other species (Fig. 4c, d, e).

The effect of position on soils, i.e., the under-plant vs. between-plant soil pattern, was much less pronounced on the NW plots than on the control plots (Figs. 1 and 4). Also, K. scoparia had less of a contrast among soils under and between its canopy than did the other species on the NW plots. This trend was significant for carbon mineralization rates and microbial biomass nitrogen levels (Fig. 4c, f).

\section{Treatment plot comparisons}

Historical resource addition significantly affected current aboveground plant biomass and tissue chemistry of the five species (Table 3 ). Total aboveground biomass was significantly higher on the $\mathrm{N}$ plots than on the other plots (Fig. 5a). Much of this increase in biomass on the $\mathrm{N}$ plots can be attributed to the very large and numerous individuals of the shrub, Artemisia frigida, on the $\mathrm{N}$ plots; this factor contributed to the significant historical treatment $\times$ species interaction effect on biomass (Table 3 ). Total belowground biomass of the five species was significantly lower on the NW plots than on control and N plots; the W plots had intermediate levels (Fig. 5b). Root to shoot ratios were also influenced by historical treatment, with ratios significantly lower on the $\mathrm{N}$ plots than on the control and W plots (Fig. $5 \mathrm{c}$ ). Carbon : nitrogen ratios of plant roots were significantly lower, and root lignin : nitrogen ratios tended to be lower than these values for the other plots (Fig. 5d, f). Carbon: nitrogen ratios of aboveground plant material were significantly lower on the NW plots than the other plots (Fig. 5e).

Although the four historical treatment plots were not significantly different from one another in total soil carbon and nitrogen, the plots that had received water (i.e., the NW and the W plots) had higher soil carbon and nitrogen than those that did not receive water, the control and $\mathrm{N}$ plots (Fig. 6a). Historical treatment also interacted with plant position to affect soil carbon and nitrogen (Table 2). More carbon and nitrogen was detected in soils under plants than in soils between plants on the control and $\mathrm{N}$ plots; this difference was not as striking or was absent in the plots that received water (Fig. 6a, b). Thus, the plots that received water had much less of a plant-induced "island of fertility" effect on soils than the plots that did not receive water. Historical treatment did not affect $\mathrm{C}$ mineralization (Fig. 

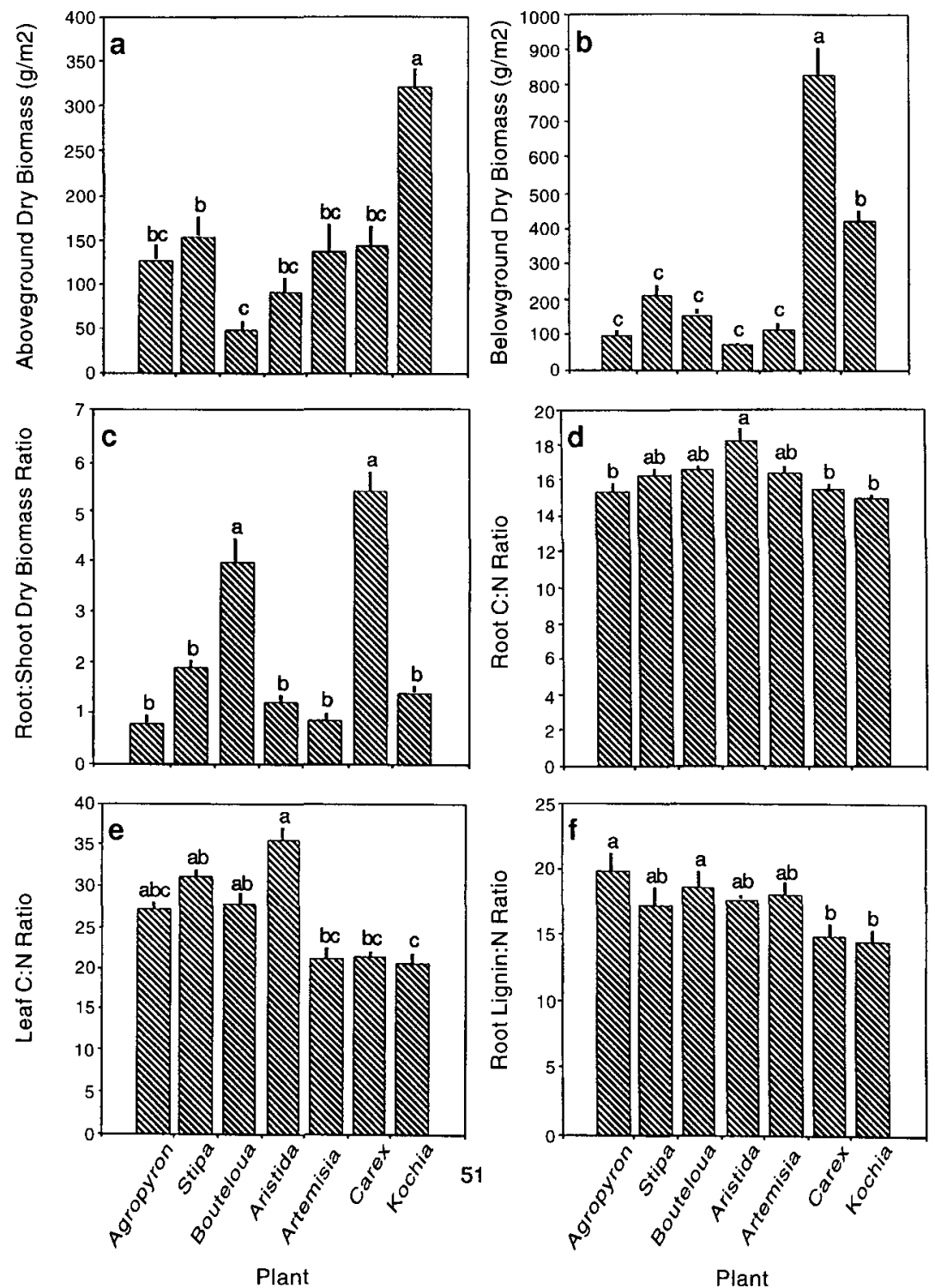

Fig. 3. Aboveground dry biomass (a), belowground dry biomass (b), root : shoot biomass ratio (c), root carbon : nitrogen ratio (d), and aboveground biomass carbon : nitrogen ratio (e) of Agropyron smithii, Stipa comata, Bouteloua gracilis, Aristida longiseta. Artemisia frigida, Carex eleocharis, and Kochia scoparia on plots receiving nitrogen plus water from 1970 to 1974 on shortgrass steppe. The vertical line on each bar indicates $1 \mathrm{SE}$. Bars with the same letters are not significantly different $(P \geq 0.05)$.

6c), but again interacted with plant presence (Table 2): the NW and W plots had significantly less of a contrast between positions in $\mathrm{C}$ mineralization than the other plots (Fig. 6c). Historical treatment affected nitrogen mineralization; the $\mathrm{N}$ and $\mathrm{NW}$ plots had higher rates of nitrogen mineralization than the control and $\mathrm{W}$ plots (Fig. 6d). As with total soil pool sizes and carbon mineralization rates, nitrogen mineralization rates were significantly higher in soils from under plants than from soils between plants, and the historical addition of water interacted with position (Table 2) to significantly decrease this contrast (Fig. 6d). No historical treatment main effects were present in microbial biomass carbon or nitrogen (Table 2, Fig. 6e, f), but, again, there was less contrast in the $\mathrm{W}$ plots in the between-plant vs. under-plant levels of microbial biomass nitrogen.

\section{Ecosystem level implications}

Soil properties expressed on a local scale, without accounting for cover proportions of plant species and bare ground, did not exhibit many differences among historical treatments (Table 2, Fig. 6), whereas soil properties expressed on a plot scale were, in most cases, significantly affected by historical treatment (Table 4). 

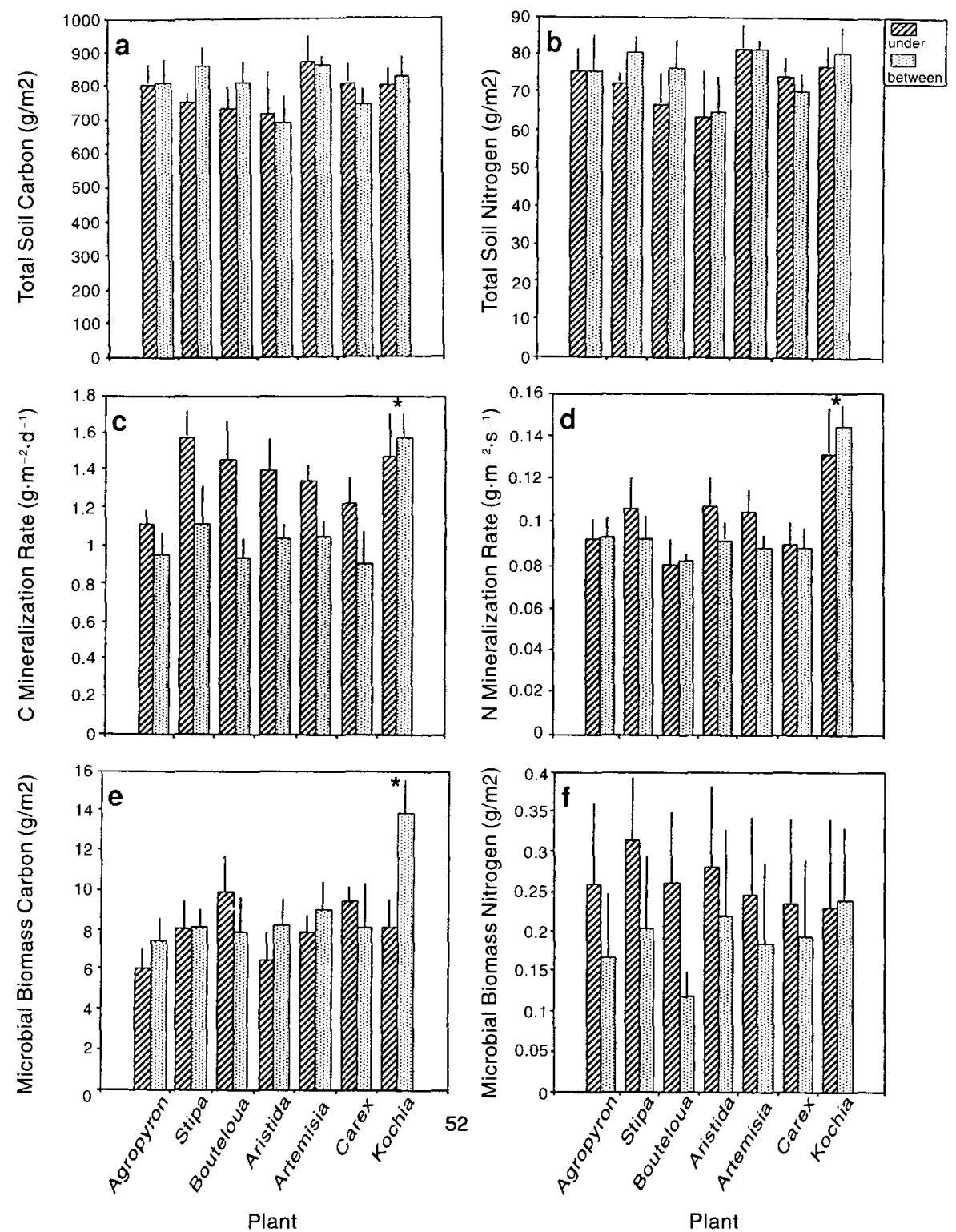

FIG. 4. Total soil carbon (a), total soil nitrogen (b), carbon mineralization rate (c), potential nitrogen mineralization rate (d), microbial biomass carbon (e), and microbial biomass nitrogen (f) in soils from under and between plants of seven species on plots in shortgrass steppe receiving nitrogen plus water from 1970 to 1974. The vertical line on each bar indicates 1 SE. Significant differences $(P<0.05)$ between soils associated with Kochia scoparia and soils under the other plant species are indicated with asterisks.

The NW plots had significantly more soil carbon and nitrogen on a plot basis than the control plots (Table 5). Nitrogen mineralization rates on a plot scale were significantly higher in the NW and N plots than the W and the control plots (Table 5). The $\mathrm{N}$ plots had higher rates of plot scale carbon mineralization than the control plots; the NW and the W plots were intermediate (Table 5). The NW plots had significantly higher plot scale microbial biomass carbon than the $\mathrm{W}$ plots, and the control and $N$ plots were intermediate. Historical treatment did not affect levels of microbial biomass nitrogen on a plot scale (Tables 4 and 5).

Different methods of calculating estimates, i.e., the consideration of individual plant or species effects, did not significantly affect the plot scale estimates of total soil carbon and nitrogen (Table 4). For both carbon and nitrogen mineralization, the estimates incorporating both average plant and plant species information (Plant and Species Estimates) resulted in significantly higher plot scale rates than the Bare Soil Estimate, an estimate 



FIG. 5. Aboveground dry biomass (a), belowground dry biomass (b), root : shoot biomass ratio (c), root carbon : nitrogen ratio (d), leaf carbon : nitrogen ratio (e) and root lignin : nitrogen ratio (f) averaged across five plant species (only Bouteloua gracilis for root lignin : $\mathrm{N}$ ) on plots in shortgrass steppe receiving nothing (Control), additional nitrogen $(\mathrm{N})$, additional water (W), or both additional nitrogen and water (NW) from 1970 to 1974. The vertical line on each bar indicates 1 SE. Bars with the same letters are not significantly different $(P \geq 0.05)$

that considered only bare ground (Table 5). The three estimates did not result in different levels of microbial biomass carbon or nitrogen (Table 5 ).

\section{DISCUSSION}

\section{Plant species and lifeform effects on soils}

This study provided evidence that plant species, via tissue chemistry, biomass allocation, or life-span (influencing spatial pattern and turnover on the landscape), affected local soil properties in shortgrass steppe. These species effects, however, were most obvious when species were grouped into categories and compared, i.e., bunchgrass vs. rhizomatous grass or annual vs. perennial. Thus, grouping species into growth forms or functional types in this system may be an adequate representation of their effects on nutrient cycling (see, for example, Chapin 1993, Mooney and Schulze 1993). Furthermore, the species (Kochia scoparia) most clearly different from the rest in terms of effects on soil properties was introduced into the native ecosystem as a result of large increases in the soil resource regime; thus it does not play a dominant role in the native, shortgrass steppe ecosystem. The soil properties affected by most species tended to be the more labile, and not the total, pools of carbon and nitrogen. This result is consistent with Wedin and Pas- 

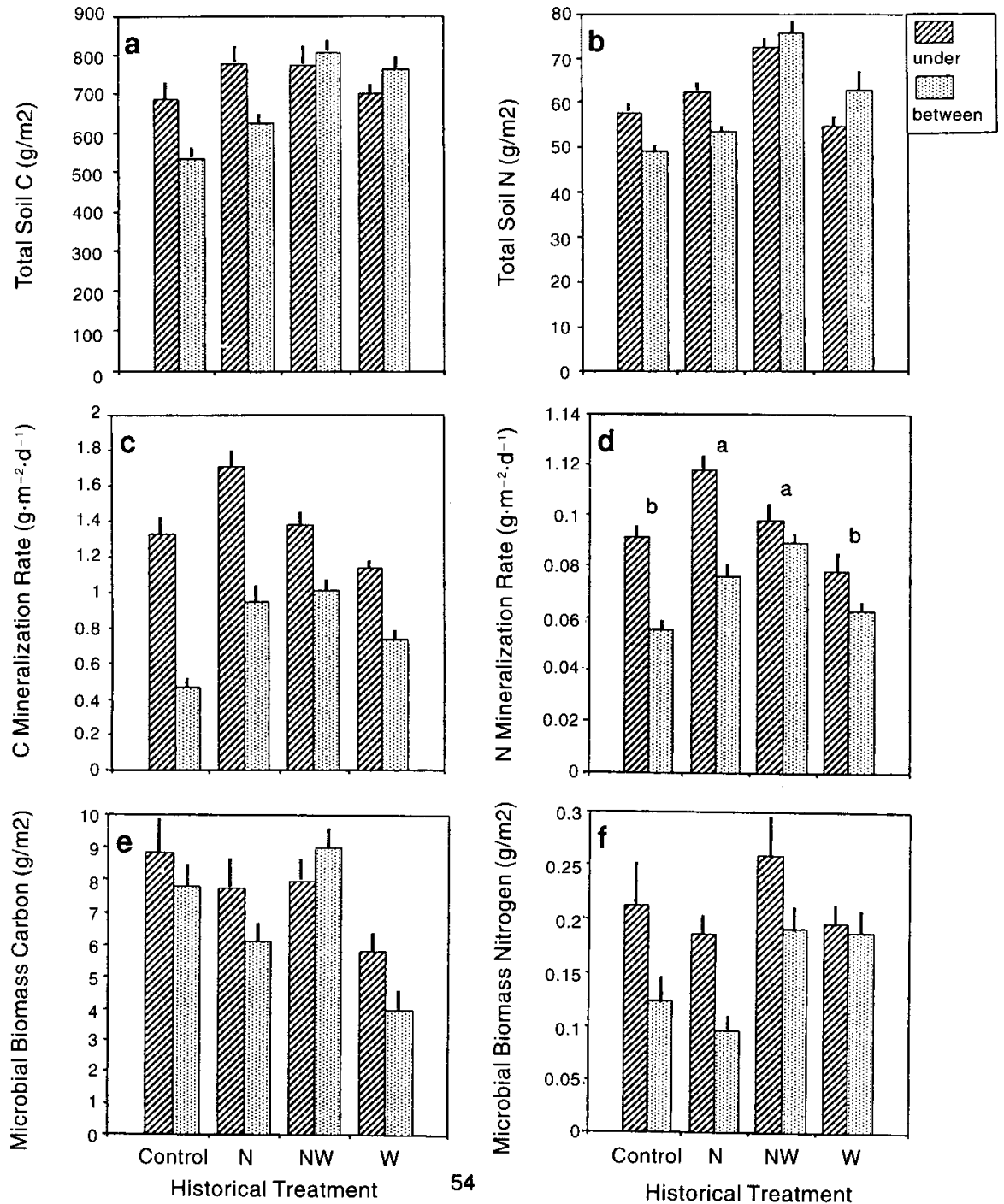

FIG. 6. Total soil carbon (a), total soil nitrogen (b), carbon mineralization rate (c), potential nitrogen mineralization rate (d), microbial biomass carbon (e), and microbial biomass nitrogen (f) in soils from under plants and between plants on plots in shortgrass steppe receiving nothing (Control), additional nitrogen $(\mathrm{N})$, additional water $(\mathrm{W})$, or both additional nitrogen and water (NW) from 1970 to 1974. Soils under and between five plant species were sampled; these data are averaged across plant species. The vertical line on each bar indicates $1 \mathrm{SE}$. Letters indicate situations where significant differences $(P<0.05)$ existed in soil properties (averaged across both under- and between-plant positions) among historical treatments.

tor (1993), who found that species effects were more obvious in the labile portions than in the recalcitrant portions of soil nitrogen. The most responsive soil property seemed to be the indices of labile carbon, and the most consistent pattern among the native species was that soils under the rhizomatous grass, Agropyron smithii, had lower carbon turnover rates and lower levels of carbon in microbial biomass than did the soils under the other, mostly bunchgrass, species. The low above- and belowground biomass of $A$. smithii may explain these patterns in soil carbon.

Frequently, plant lignin or lignin : nitrogen and carbon : nitrogen ratios are viewed as important variables determining soil nutrient availability and cycling, particularly nitrogen mineralization rates (Melillo et al. 1982, Pastor and Post 1986, Wedin and Tilman 1990, Stump and Binkley 1993). In general, we found that species with the highest nitrogen mineralization rates in soils beneath their canopy also had the lowest root lignin : nitrogen and carbon : nitrogen ratios (e.g., Stipa comata and, in the NW plots, $K$. scoparia). Nitrogen mineralization in the soil beneath the plant canopy reflects combined effects of a number of potentially controlling and interacting factors, including tissue chemical quality as well as tissue quantity. Van Vuuren and van der Eerden (1992) have demonstrated that plant 
TABLE 5. Three estimates* of ecosystem values of total soil carbon, total soil nitrogen, carbon mineralization rates, potential nitrogen mineralization rates, microbial biomass carbon, and microbial biomass nitrogen on plots in shortgrass steppe receiving additional nitrogen $(\mathrm{N})$, additional water $(\mathrm{W})$, both additional nitrogen and water (NW), or nothing (Control) from 1970 to 1974. Data represent mean \pm SE. Estimates with the same letter superscript are not significantly different $(P>0.05)$ when averaged over historical treatments. Historical treatments with the same letter are not significantly different $(P>0.05)$ when averaged over estimate.

\begin{tabular}{|c|c|c|c|c|}
\hline \multirow[b]{2}{*}{ Estimate } & \multicolumn{4}{|c|}{ Historical treatment } \\
\hline & Control & $\mathrm{N}$ & NW & $\mathbf{W}$ \\
\hline & \multicolumn{4}{|c|}{ Total soil carbon $(\mathrm{kg} / \mathrm{ha})$} \\
\hline & $\mathrm{b}$ & $\bar{a}$ & $\mathrm{a}$ & $\mathbf{a}$ \\
\hline Bare soila & $5350 \pm 21$ & $6259 \pm 618$ & $7973 \pm 256$ & $7615 \pm 687$ \\
\hline Plant & $6560 \pm 276$ & $7502 \pm 277$ & $7804 \pm 178$ & $7119 \pm 130$ \\
\hline \multirow[t]{3}{*}{ Species $^{\mathrm{a}}$} & $6369 \pm 347$ & $7646 \pm 135$ & $7930 \pm 164$ & $6996 \pm 266$ \\
\hline & \multicolumn{4}{|c|}{ Total soil nitrogen (kg/ha) } \\
\hline & $b$ & ab & a & $a b$ \\
\hline Bare soila & $491 \pm 12$ & $534 \pm 10$ & $755 \pm 21$ & $626 \pm 152$ \\
\hline Plant & $560 \pm 45$ & $609 \pm 52$ & $732 \pm 2$ & $563 \pm 96$ \\
\hline \multirow[t]{3}{*}{ Species $^{\mathrm{a}}$} & $538 \pm 51$ & $626 \pm 63$ & $746 \pm 24$ & $554 \pm 104$ \\
\hline & \multicolumn{4}{|c|}{ Carbon mineralization $\left(\mathrm{kg} \mathrm{h} \mathbf{h}^{-1} \mathbf{d}^{-1}\right)$} \\
\hline & $\mathrm{b}$ & $\mathrm{a}$ & $\mathrm{ab}$ & $\mathrm{ab}$ \\
\hline Bare soill & $4.7 \pm 0.1$ & $9.5 \pm 3.9$ & $10.8 \pm 0.9$ & $7.4 \pm 1.1$ \\
\hline Plant $^{\mathrm{a}}$ & $11.4 \pm 0.8$ & $15.8 \pm 1.2$ & $13.5 \pm 1.3$ & $10.6 \pm 1.6$ \\
\hline \multirow[t]{3}{*}{ Species $^{\mathrm{a}}$} & $11.5 \pm 0.9$ & $15.8 \pm 1.8$ & $13.3 \pm 1.1$ & $10.5 \pm 1.5$ \\
\hline & \multicolumn{4}{|c|}{ Nitrogen mineralization $\left(\mathrm{kg} \mathrm{ha}^{-1} \mathrm{~d}^{-1}\right)$} \\
\hline & $b$ & a & a & $\mathrm{b}$ \\
\hline Bare soilb & $0.56 \pm 0.01$ & $0.76 \pm 0.09$ & $0.97 \pm 0.03$ & $0.63 \pm 0.06$ \\
\hline Plant $^{\mathrm{a}}$ & $0.84 \pm 0.09$ & $1.11 \pm 0.01$ & $1.01 \pm 0.08$ & $0.75 \pm 0.09$ \\
\hline \multirow[t]{3}{*}{ Species ${ }^{\mathrm{a}}$} & $0.84 \pm 0.10$ & $1.10 \pm 0.09$ & $1.06 \pm 0.07$ & $0.71 \pm 0.09$ \\
\hline & \multicolumn{4}{|c|}{ Microbial biomass carbon $(\mathrm{kg} / \mathrm{ha})$} \\
\hline & ab & $a b$ & $a$ & $\mathrm{~b}$ \\
\hline Bare soill & $78 \pm 3$ & $61 \pm 11$ & $89 \pm 3$ & $40 \pm 7$ \\
\hline Plant & $85 \pm 10$ & $74 \pm 19$ & $79 \pm 10$ & $55 \pm 12$ \\
\hline \multirow[t]{3}{*}{ Species ${ }^{3}$} & $80 \pm 9$ & $81 \pm 23$ & $83 \pm 15$ & $55 \pm 11$ \\
\hline & \multicolumn{4}{|c|}{ Microbial biomass nitrogen (kg/ha) } \\
\hline & $a$ & $a$ & $\mathrm{a}$ & a \\
\hline Bare soila & $1.2 \pm 0.9$ & $1.0 \pm 0.3$ & $1.9 \pm 1.2$ & $1.8 \pm 0.7$ \\
\hline Plant $^{\mathrm{a}}$ & $1.9 \pm 1.2$ & $1.7 \pm 0.6$ & $2.6 \pm 1.7$ & $1.9 \pm 0.7$ \\
\hline Species ${ }^{a}$ & $1.9 \pm 1.2$ & $1.8 \pm 0.8$ & $2.4 \pm 1.7$ & $1.9 \pm 0.7$ \\
\hline
\end{tabular}

* The Bare Soil Estimate represents no consideration of plant effects on soils. The Plant Estimate includes effects of plant presence or absence, without consideration of differential cover or nutrient cycling characteristics among species. The Species Estimate includes the effects of all major plant species, including their relative cover and nutrient cycling characteristics. See Methods for an explanation of how each estimate was calculated.

species can have differential effects on both microbial immobilization and microbial release of nutrients. In our study, Bouteloua gracilis had fairly low nitrogen mineralization rates in its soils but did not have the highest root lignin : nitrogen or leaf and root carbon: nitrogen ratios. $B$. gracilis also had fairly high belowground biomass and root: shoot ratios, suggesting that microbial immobilization of nitrogen may have significantly decreased net nitrogen mineralization in the incubations of $B$. gracilis soil and other species' soil with large amounts of fine root litter. In a root exudation study (Biondini et al. 1988), B. gracilis released more $\mathrm{C}$ and $\mathrm{N}$ from roots in sterile media than $A$. smithii; however, we did not detect any significant differences in microbial levels or activity between the two.
Plant species effects were also apparent in the degree of between-plant canopy vs. under-plant canopy differences in soil properties. $K$. scoparia, the only annual in the study, showed significantly less plant canopyinduced soil variation in carbon mineralization rates and microbial biomass nitrogen than did the perennial species. As an annual, $K$. scoparia plants presumably occupy microsites only briefly, with different microsites occupied each year. Also, bunchgrasses tended to have more of a contrast in soil properties in betweenplant canopy vs. under-plant canopy positions than did the non-bunch life-forms. This difference could be explained by the spatial arrangement of stems. Bunchgrasses tend to have very localized points of biomass, in contrast to more diffuse or "stemmy" herbaceous 
life-forms, such as rhizomatous grasses. Mazzarino et al. (1991), in a dry Chaco ecosystem in Argentina, also showed differences in plant-associated soil heterogeneity, depending upon the plant type. In that system, soils under trees were significantly higher in nitrogen mineralization than soils in interspaces, whereas soils under grasses were similar to the interspace soils. Lauenroth et al. (in press) showed differences in plantassociated soil heterogeneity, apparently determined by the life-span of the plant, with the shorter-lived plant, Bouteloua eriopoda, having less between vs. under canopy difference in soils than the longer-lived plant, $B$. gracilis. In a study of the amount of soil heterogeneity around individual plants in a sagebrush steppe ecosystem, Jackson and Caldwell (1993) found stronger spatial patterning in soils associated with tussock grasses than soils associated with sagebrush plants.

\section{Plant cover effects on soils}

Discontinuous plant cover is an obvious feature of shortgrass steppe ecosystems and this spatial heterogeneity in plant presence had strong and consistent effects on soil properties, particularly the active soil pools. Soil under plants had higher total and mineralizable carbon and higher microbial biomass and mineralizable nitrogen than soil between plants. Individual plants concentrate biomass and thus carbon and nitrogen in the soil beneath their canopy, leading to a plant-induced "island of soil fertility" effect, often observed in arid and semiarid areas (Charley and West 1975, 1977, Barth and Klemmedson 1978, Klopatek 1987, Burke et al. 1989, Bolton et al. 1990, 1993, Schlesinger et al. 1990, Hook et al. 1991). Historical addition of resources, particularly water, in many cases diminished or eliminated this plant-induced heterogeneity. This breakdown in plant-induced soil pattern is probably due to increased turnover of plants on the landscape, resulting from increased mortality of native plants and increased recruitment of new plants, especially those with an annual life-span. Increased turnover of plants on the landscape may have resulted in plants occupying given locations for a shorter period of time. Bolton et al. (1990), in studies of a semiarid grassland in southeastern Washington, also showed less plant-induced soil heterogeneity in annual plant stands than in perennial shrub steppe stands. Schlesinger et al. (1990) have suggested that increased plant-induced soil heterogeneity, initiated by grazing in the southwestern U.S. desert system, leads to ecosystem degradation and desertification. In our system, this heterogeneity seems to be a feature of native shortgrass steppe, and the disruption of that heterogeneity, initiated by nutrient and water addition in this case, was associated with unprecedented changes in plant production and species composition.

\section{Historical treatment effects on plants and soils}

The historical addition of soil resources to shortgrass steppe in the early 1970s affected plant biomass and allocation in the early 1990s. Numerous experiments and reviews (e.g., Mooney 1972, Chapin 1980, Tilman and Cowan 1989) have shown that plant root: shoot ratios decrease under conditions of enhanced belowground resources, and our data show the same pattern. Apparently, $20 \mathrm{yr}$ after fertilization, the additional nitrogen on the $\mathrm{N}$ plots is still available to plants and allows them to maintain high levels of tissue nitrogen relative to carbon as well as to invest relatively less in production of roots. Such a response may involve a positive feedback between the plant characteristics of biomass allocation and litter quality and soil resource availability. Although responses of plant nutrient allocation to resource additions are often observed, our study shows that responses can persist through time and may be stabilized by interactions between plants and soils.

Historical resource addition has also caused persistent changes in soil characteristics, via the activity of plants. The addition of water in the early 1970 s resulted in large increases in net primary production (Lauenroth et al. 1978); the high current levels of soil carbon on the historical $\mathrm{W}$ plots likely reflect this production pulse twenty yr ago. Although current total pools of soil nitrogen were not detectably larger in the plots which received nitrogen from 1970 to 1974, active pools (sensu Parton et al. 1987), as indicated by nitrogen mineralization rates, were significantly higher in these plots. Furthermore, the plants on the historical nitrogen addition plots had lower carbon : nitrogen tissue ratios. This suggests that at least a portion of the added nitrogen is still present in active soil pools and has been incorporated into plant tissue. In turn, during the $20 \mathrm{yr}$ since fertilization, the labile plant tissue has probably contributed to the active soil pool of nitrogen. This result represents further evidence for linkages and feedbacks between soils and plants in this system and is consistent with earlier work showing tight linkages in the nitrogen cycle between Bouteloua gracilis plants and soil (Clark 1977).

Plant-soil patterns on the historically resourceamended area suggest that positive feedbacks between plants and soil nutrients may be initiated and persist for many years, even in an ecosystem traditionally viewed as being limited primarily by water. Kochia scoparia was only able to invade and dominate this ecosystem under artificially high soil resource conditions, resulting from water and nitrogen fertilizer additions. However, when additions were stopped (20 yr ago), the abundance or productivity of $K$. scoparia did not drop to previous levels. Our data suggest that high nitrogen availability in soils beneath $K$. scoparia may be maintained in part by tissue chemistry favorable to microbial decomposition and release of nitrogen. The continued persistence of $K$. scoparia, in turn, may involve its superior competitive ability on nutrient-rich soils and/or possible allelopathic effects on other species (Karachi and Pieper 1987). The fact that invasive 
plant species such as this one can initiate and maintain profound changes in ecosystem function has important implications for disturbed or island systems, or any ecosystem undergoing large changes in plant species composition (Vitousek 1986, 1990, Vitousek et al. 1987).

\section{Ecosystem level implications}

Our ecosystem level estimates of soil properties serve to emphasize the importance of local plant effects on soils. The estimate (Bare Soil) that did not incorporate local plant presence effects on soils resulted in very different calculated plot level properties than the estimates (Plant and Species) that did include plant information. However, despite some of the large effects of plant species on local soil properties, the addition of information about plant species in most cases did not have large effects on estimates of plot level soil properties. This result indicates that, although plant species may have differential local effects on soils, it is the presence, and not so much the identity, of the plant occupying a given space that may be most important to plot level estimates of soil properties in this semiarid grassland. In some cases (e.g., perennial vs. annual species) the plant species identity determines the year-to-year pattern in plant presence. Padien and Lajtha (1992) found similar results in that the presence or absence of a canopy in pinyon-juniper communities was more important to soil nitrogen dynamics on a local scale than differences among the particular species forming the canopy. We believe that in our semiarid ecosystem, the importance of plant presence may overshadow that of plant species in ecosystem level estimates because (1) plant presence is discontinuous and (2) decomposition and nutrient availability are primarily limited by water, not by plant species-mediated characteristics such as litter quality.

This study has shown that perturbations in soil resources can persist for long periods of time $(>20 \mathrm{yr})$ and furthermore, these perturbations to soil resources may persist and be maintained through feedbacks between soil organic matter and plant species characteristics. In addition, we have shown that plant species may have differential effects on soil properties but, in this system, the presence of a plant rather than the identity of the plant is the most important determinant of ecosystem level soil property estimates. That local plant-induced patterns in soil properties significantly affected ecosystem scale estimates indicates that consideration of structural attributes, particularly plant cover patterns, is critical to estimates of ecosystem function in shortgrass steppe.

\section{ACKNOWLEDGMENTS}

We thank P. B. Hook, D. L. Urban, D. P. Coffin, O. E. Sala, and $W$. K. Lauenroth for providing helpful reviews of the manuscript. G. R. Shaver and two anonymous reviewers also improved the manuscript substantially. We appreciate the help of L. Spears, T. Ihori, and D. Reuss in the field and laboratory.
P. Chapman provided assistance on the statistical analyses. Funding was provided by a NSF Doctoral Dissertation Improvement Award (DEB-9213180) and NSF grant BSR8114822 for the shortgrass steppe Long-Term Ecological Research Program.

\section{Literature Cited}

Amato M., and J. N. Ladd. 1988. Assay for microbial biomass based on ninhydrin-reactive nitrogen in extracts of fumigated soils. Soil Biology and Biochemistry 20:107114.

Barth, R. C., and J. O. Klemmedson. 1978. Shrub-induced spatial patterns of dry matter, nitrogen and organic carbon. Soil Science Society of America Journal 42:804-809.

Berendse, F., R. Bobbink, and G. Rouwenhorst. 1989. A comparative study on nutrient cycling in wet heathland ecosystems II: litter decomposition and nutrient mineralization. Oecologia 78:338-348.

Binkley, D., and D. Valentine. 1991. Fifty-year biogeochemical effects of green ash, white pine, and Norway spruce in a replicated experiment. Forest Ecology and Management 40:13-25.

Biondini, M., D. A. Klein, and E. F. Redente. 1988. Carbon and nitrogen losses through root exudation by Agropyron cristatum, A. smithii and Bouteloua gracilis. Soil Biology and Biochemistry 20:477-482.

Bolton, J., J. L. Smith, and S. O. Link. 1993. Soil microbial biomass and activity of a disturbed and undisturbed shrubsteppe ecosystem. Soil Biology and Biochemistry 25:545552.

Bolton, H., J. L. Smith, and R. E. Wildung. 1990. Nitrogen mineralization potential of shrub-steppe soils with different disturbance histories. Soil Science Society of America Journal 54:887-891.

Brookes, P. C., A. Landman, G. Pruden, and D. S. Jenkinson. 1985. Chloroform fumigation and the release of soil nitrogen: a rapid direct extraction method to measure microbial biomass nitrogen in soil. Soil Biology and Biochemistry 17:837-842.

Burke, I. C. 1989. Control of $\mathrm{N}$ mineralization in a sagebrush steppe landscape. Ecology 70:1115-1126.

Burke, I. C., W. A. Reiners, and D. S. Schimel. 1989. Organic matter turnover in a sagebrush steppe landscape. Biogeochemistry 7:11-31.

Chapin, F. S. 1980. The mineral nutrition of wild plants. Annual Review of Ecology and Systematics 11:233-260.

. 1993. Functional role of growth forms in ecosystem and global processes. Pages 287-319 in J. R. Ehleringer and C. B. Field, editors. Scaling physiological processes: leaf to globe. Academic Press, London, England.

Charley, J. L., and N. E. West. 1975. Plant-induced soil chemical patterns in some shrub-dominated semi-desert ecosystems of Utah. Journal of Ecology 63:945-963.

Charley, J. L., and N. E. West. 1977. Micro-patterns of nitrogen mineralization activity in soils of some shrub-dominated semi-desert ecosystems of Utah. Soil Biology and Biochemistry 9:357-365.

Clark, F. E. 1977. Internal cycling of ${ }^{15}$ Nitrogen in shortgrass prairie. Ecology 58:1322-1333.

Dodd, J. D., and W. K Lauenroth. 1978. Analyses of the response of a grassland ecosystem to stress. Pages $43-58$ in N. R. French, editor. Perspectives in grassland ecology. Springer-Verlag, New York, New York, USA.

EPA. 1979. Methods for chemical analysis of water and wastes. EPA-600/4-79-020, March 1979, U.S. Environmental Protection Agency. U.S. Government Printing Office, Washington, D.C., USA.

Gomez, K., and A. Gomez. 1984. Statistical procedures for agricultural research. Wiley Interscience, New York, New York, USA.

Great Plains Flora Association. 1986. Flora of the Great 
Plains. University Press of Kansas, Lawrence, Kansas, USA.

Grime, J. P. 1979. Plant strategies and vegetation processes. John Wiley and Sons, Chichester, England.

Hobbie, S. E. 1992. Effects of plant species on nutrient cycling. Trends in Ecology and Evolution 7:336-339.

Hook, P. B., I. C. Burke, and W. K. Lauenroth. 1991. Heterogeneity of soil and plant $\mathrm{N}$ and $\mathrm{C}$ associated with individual plants and openings in North American shortgrass steppe. Plant and Soil 138:247-256.

Inouye, R. S., and D. Tilman. 1988. Convergence and divergence of old-field plant communities along experimental nitrogen gradients. Ecology 69:995-1004.

Jackson, R. B., and M. M. Caldwell. 1993. Geostatistical patterns of soil heterogeneity around individual perennial plants. Journal of Ecology 81:683-692.

Johnson, L. C., and A. W. H. Damman. 1991. Species-controlled Sphagnum decay on a South Swedish raised bog. Oikos 61:234-242.

Karachi, M., and R. D. Pieper. 1987. Allelopathic effects of kochia on blue grama. Journal of Range Management 40: 380-381.

Karimian, N., and K. Razmi. 1990. Influence of perennial plants on chemical properties of arid calcareous soils in Iran. Soil Science 150:717-721.

Klemmedson, J. O. 1991. Oak influence of nutrient availability in pine forests of central Arizona. Soil Science Society of America Journal 55:248-253.

Klopatek, J. M. 1987. Nitrogen mineralization and nitrification in mineral soils of pinyon-juniper ecosystems. Soil Science Society of America Journal 51:453-457.

Lauenroth, W. K., D. P. Coffin, I. C. Burke, and R. A. Virginia. In press. Effects of plant mortality on population dynamics and ecosystem structure: a case study. In T. M. Smith, H. H. Shugart, and F. I. Woodward, editors. Plant functional types. Cambridge University Press, Cambridge, England.

Lauenroth, W. K., and J. L. Dodd. 1979. Response of native grassland legumes to water and nitrogen treatments. Journal of Range Management 32:292-294.

Lauenroth, W. K., J. L. Dodd, and P. L. Sims. 1978. The effects of water- and nitrogen-induced stresses on plant community structure in a semiarid grassland. Oecologia 36: 211-222.

Lauenroth, W. K., and W. C. Whitman. 1971. A rapid method for washing roots. Journal of Range Management 24:308309.

Matson, P. 1990. Plant-soil interactions in primary succession at Hawaii Volcanoes National Park. Oecologia 85: 241-246.

Mazzarino, M. J., L. Oliva, A. Nunez, G. Nunez, and E. Buffa. 1991. Nitrogen mineralization and soil fertility in the dry Chaco ecosystem (Argentina). Soil Science Society of America Journal 55:515-522.

Melillo, J. M., J. D. Aber, and J. F. Muratore. 1982. Nitrogen and lignin control of hardwood leaf litter decomposition dynamics. Ecology 63:621-626.

Milchunas, D. G., and W. K. Lauenroth. 1995. Inertia in plant community structure: state changes after cessation of nutrient-enrichment stress. Ecological Applications 5:452458.

Milchunas, D. G., W. K. Lauenroth, P. L. Chapman, and M. K. Kazempour. 1990. Community attributes along a perturbation gradient in a shortgrass steppe. Journal of Vegetation Science 1:375-384

Mooney, H. A. 1972. The carbon balance of plants. Annual Review of Ecology and Systematics 3:315-346.

Mooney, H. A., and E. Schulze. 1993. Biodiversity and ecosystem function. Springer Verlag, New York, New York, USA.

Padien, D. J., and K. Lajtha. 1992. Plant spatial pattern and nutrient distribution in pinyon-juniper woodlands along an elevational gradient in northern New Mexico. International Journal of Plant Science 153:425-433.

Parton, W. J., and D. Greenland. 1987. Central Plains Experimental Range Site, Colorado. Pages 23-27 in D. Greenland, editor. The climates of the long-term ecological research sites. Occasional Paper No. 44, Institute of Arctic and Alpine Research, University of Colorado, Boulder, Colorado, USA

Parton, W. J., D. S. Schimel, C. V. Cole, and D. S. Ojima. 1987. Analysis of factors controlling soil organic matter levels in Great Plains grasslands. Soil Science Society of America Journal 51:1173-1179.

Pastor, J., J. D. Aber, C. A. McClaugherty, and J. M. Melillo. 1984. Aboveground production and $\mathrm{N}$ and $\mathrm{P}$ cycling along a nitrogen mineralization gradient on Blackhawk Island, Wisconsin. Ecology 65:256-268.

Pastor, J., B. Dewey, R. J. Naiman, P. F. McInnes, and Y. Cohen. 1993. Moose browsing and soil fertility in the boreal forests of Isle Royale National Park. Ecology 74 $467-480$.

Pastor, J., and W. M. Post. 1986. Influence of climate, soil moisture, and succession on forest carbon and nitrogen cycle. Biogeochemistry 2:3-27.

Powlson, D. S., and D. S. Jenkinson. 1976. The effects of biocidal treatments on metabolism in soil-II. Gamma irradiation, autoclaving, air-drying and fumigation. Soil $\mathrm{Bi}-$ ology and Biochemistry 8:179-188.

Reiners, W. A., I. A. Worley, and D. B. Lawrence. 1971. Plant diversity in a chronosequence at Glacier Bay, Alaska. Ecology 52:55-69.

Rice, E. L., and S. K. Pancholy. 1972. Inhibition of nitrification by climax ecosystems. American Journal of Botany 59:1033-1040.

Robertson, G. P., M. A. Huston, F. C. Evans, and J. M. Tiedje. 1988. Spatial variability in a successional plant community: patterns of nitrogen availability. Ecology 69:15171524.

SAS institute. 1985. SAS statistics. SAS Institute, Cary, North Carolina, USA.

Schimel, D. S. 1986. Carbon and nitrogen turnover in adjacent grassland and cropland ecosystems. Biogeochemistry $2: 345-357$.

Schlesinger, W. H., J. F. Reynolds, G. L. Cunningham, L. F. Huenneke, W. M. Jarrell, R. A. Virginia, and W. G. Whitford. 1990. Biological feedbacks in global desertification. Science 247: 1043-1047.

Snyder, J. D., and J. A. Trofymow. 1984. A rapid accurate wet oxidation diffusion procedure for determining organic and inorganic carbon in plant and soil samples. Communications in Soil Science and Plant Analysis 15:587-597.

Stump, L. M., and D. Binkley. 1993. Relationships between litter quality and nitrogen availability in Rocky Mountain forests. Canadian Journal of Forest Research 23:492-502.

Tilman, D. 1986. Nitrogen-limited growth in plants from different successional stages. Ecology 67:555-563.

Tilman, D., and M. L. Cowan. 1989. Growth of old field herbs on a nitrogen gradient. Functional Ecology 3:425438 .

Tilman, D., and D. Wedin. 1991. Dynamics of nitrogen competition between successional grasses. Ecology 72:10381049.

Van Soest, P. F. 1963. Use of detergents in the analysis of fibrous feeds. II. A rapid method for the determination of fiber and lignin. Journal of the Association of Official Analytical Chemists 46:829-835.

Van Vuuren, M. M. I., and L. J. van der Eerden. 1992. Effects of three rates of atmospheric nitrogen deposition enriched with ${ }^{15} \mathrm{~N}$ on litter decomposition in a heathland. Soil Biology and Biochemistry 24:527-532. 
Vitousek, P. M. 1986. Biological invasions and ecosystem properties: can species make a difference? Pages 163-176 in H. A. Mooney and J. Drake, editors. Biological invasions of North America and Hawaii. Springer-Verlag, New York, New York, USA.

1990. Biological invasions and ecosystem processes: towards an integration of population biology and ecosystem studies. Oikos 57:7-13.

Vitousek, P. M., L. R. Walker, L. D. Whiteaker, D. MuellerDombois, and P. A. Matson. 1987. Biological invasion by
Myrica faya alters ecosystem development in Hawaii. Science 238:802-804.

Waldern, D. E. 1971. A rapid micro-digestion procedure for neutral and acid detergent fiber. Canadian Journal of Animal Science 51:67-69.

Wedin, D. A., and J. Pastor. 1993. Nitrogen mineralization dynamics in grass monocultures. Oecologia 96: 186-192.

Wedin, D. A., and D. Tilman. 1990. Species effects on nitrogen cycling: a test with perennial grasses. Oecologia 84: $433-441$ 